日十二月儿年一个四治明

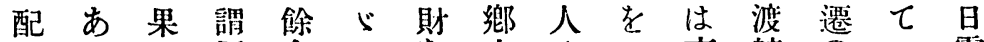
さる、優 命め古は

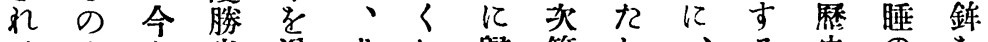

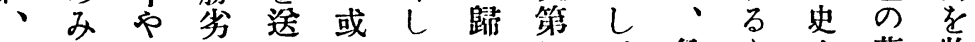

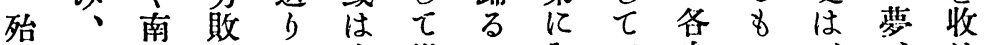

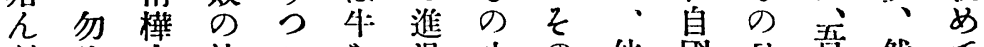

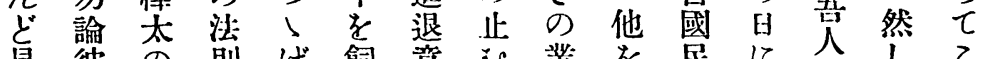

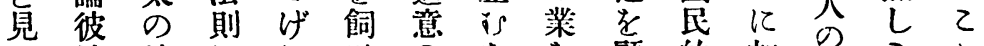

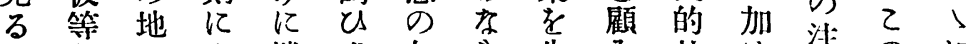

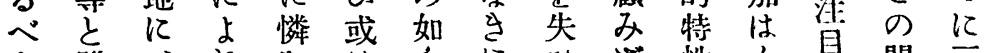

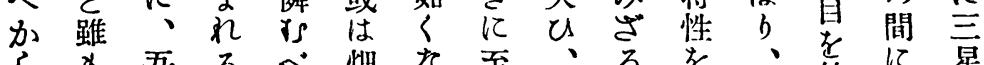

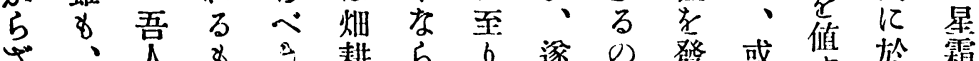
艺自䒘 の然迎な態てるなは栐し漁合る過

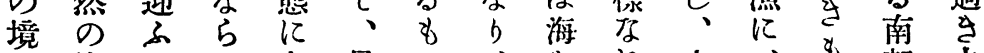

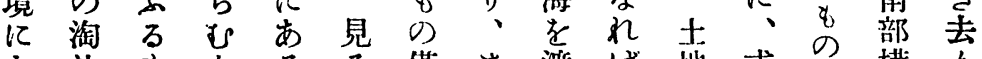

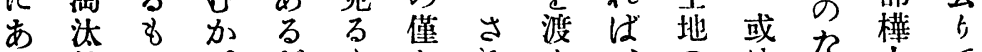

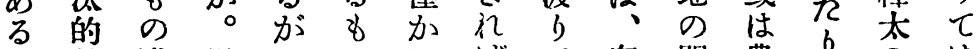
少务去乙炡影今、住發に邦幾焉

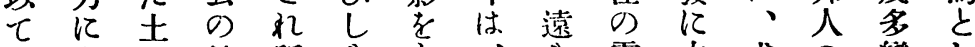
支人結 所主と、包露力或の 繂し

先はな指等記し、至的何

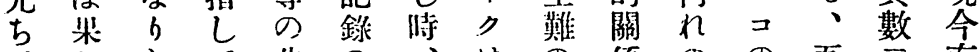

てしと尜の、はの係の の吾三南至解予

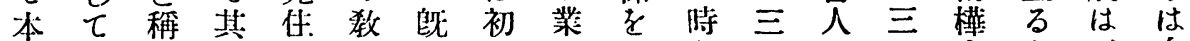

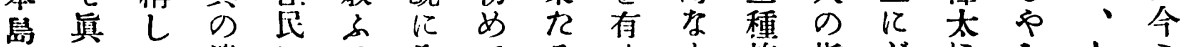

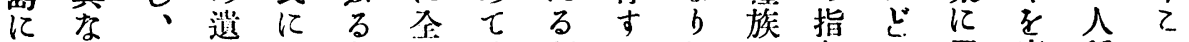

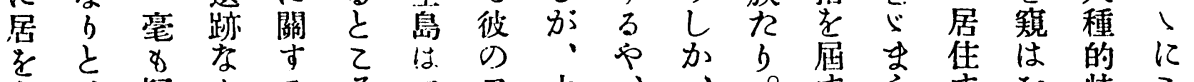

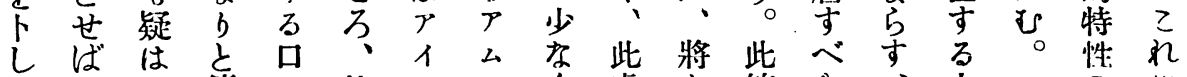

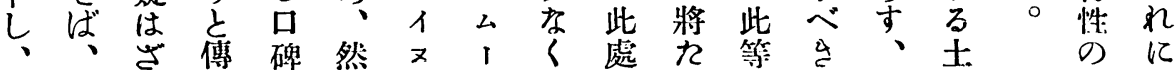

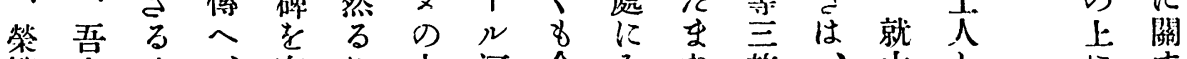

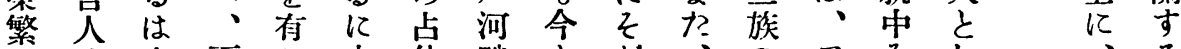

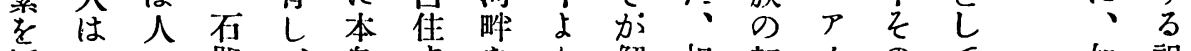

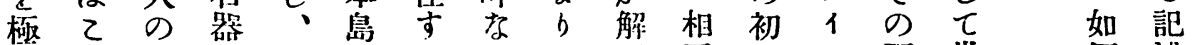

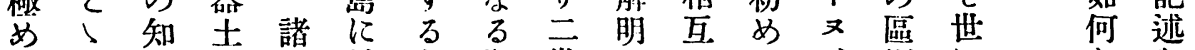

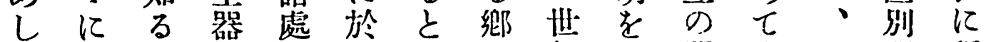

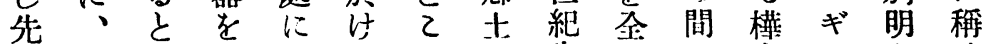

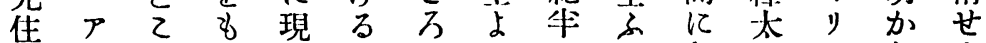

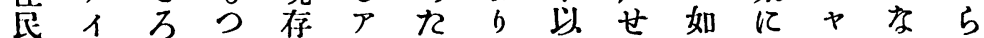

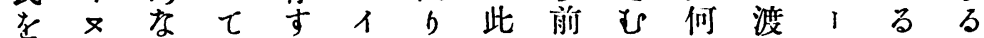
追のる其る

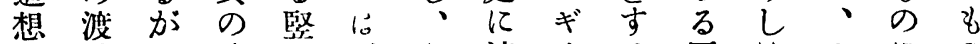

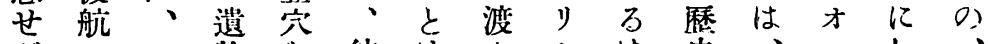

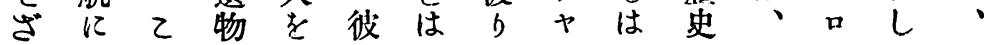

な 索 る 試 茼 み 整罚 点異 す 族 る 0) に接 


\section{號 十七百二第誌雜會學類人京東}

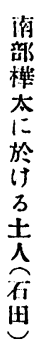

のるれに $ら$ 然しは $し$ 前 有㔔り陷け從の其九訅

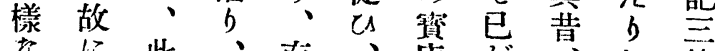
江此、南、㡹㤎、し 族 、彼海逐方北考活来は叹 彼等崖海方占舞芯、! 等の と の生的西露大漁劣族然者

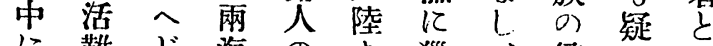
は擎 ど

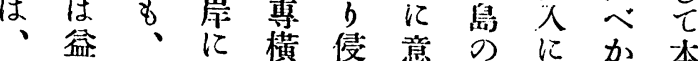
種々年々に人妾北遭ら帛

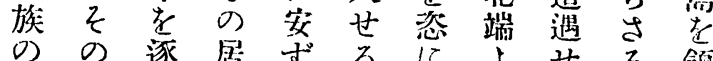

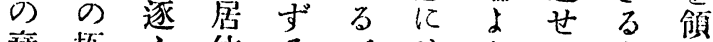

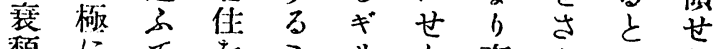

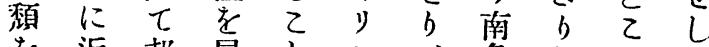
近帮局之学、角し 万就 憂つ人せ能、然に時な の

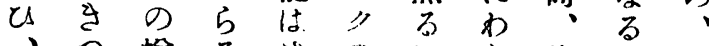

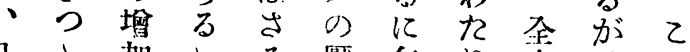

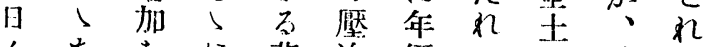

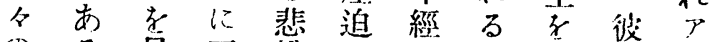

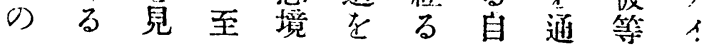

に篇案すす留 算 る

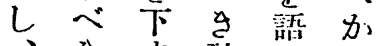

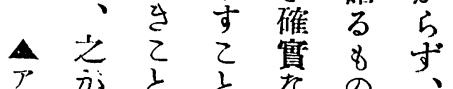
方之学尔の、 簡に不るにさ なあ可證方れ るら 能據あ ど 訑さ热省占口 述るる萖さ碑 老が集れ傳 試当、世竐 みつ斯 五、尔 引て 万る 其る 今 問 間 の \% 䟎は傅 の たは、説、 、予加 艄 予 b 是 現の民各し 住此め非 の處索交

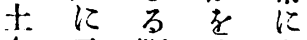
人云断决事

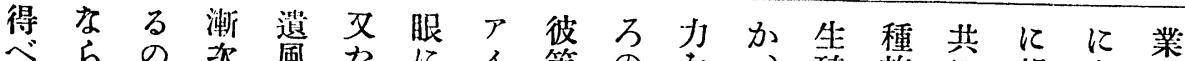

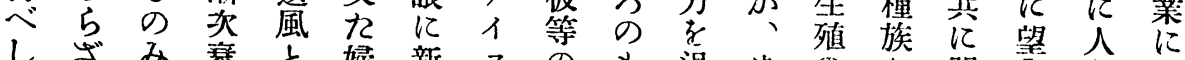

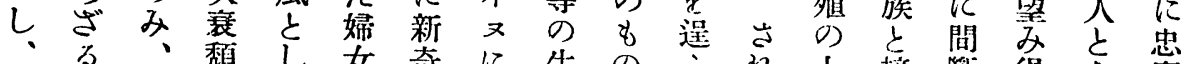

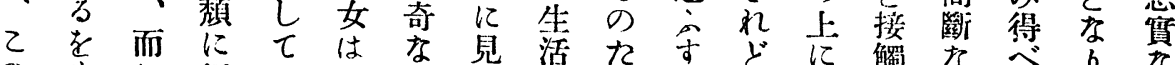

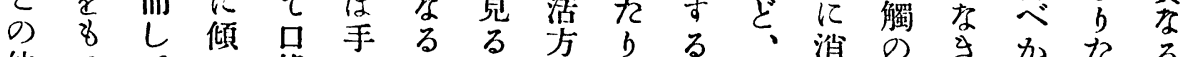

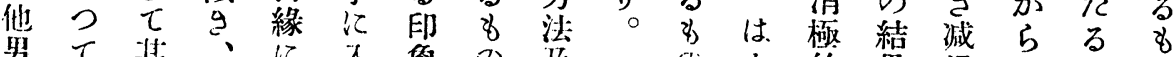

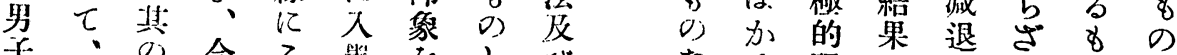

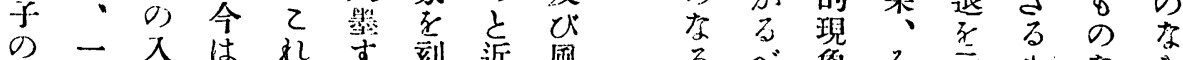

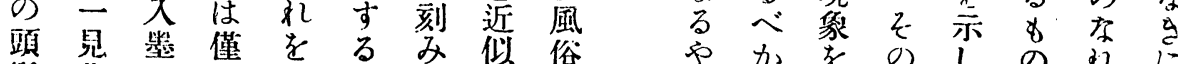

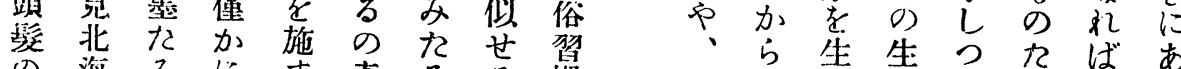
の海る に专 る

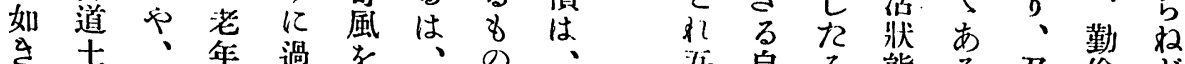

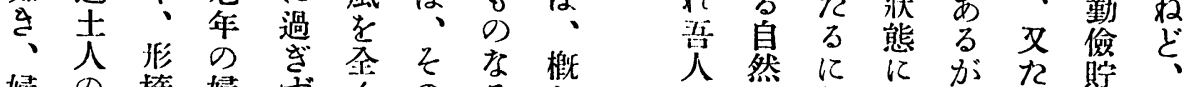
人婦 の 楕 婦 寸゙ く 人 そ 買 人

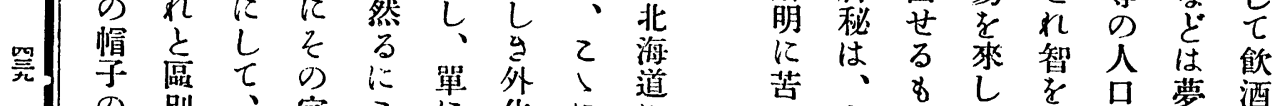

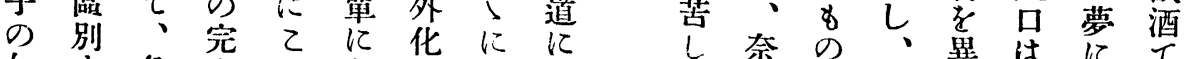

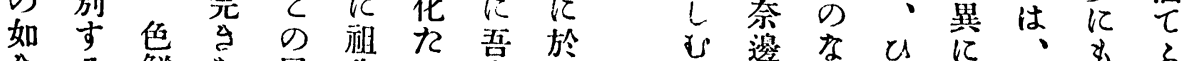

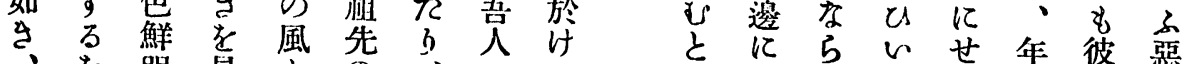
を明兒\&宁のる 之其して る と等習 


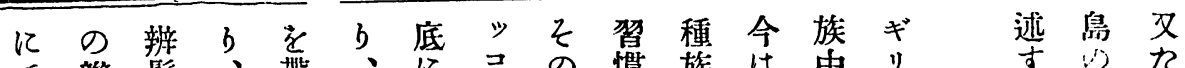

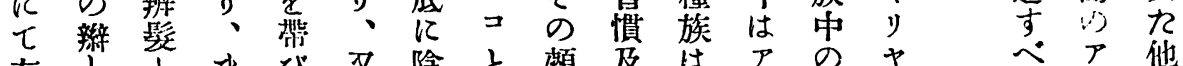

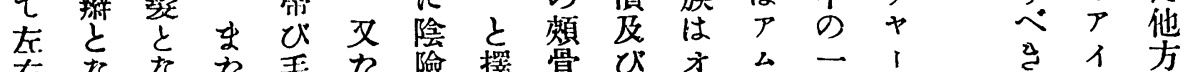

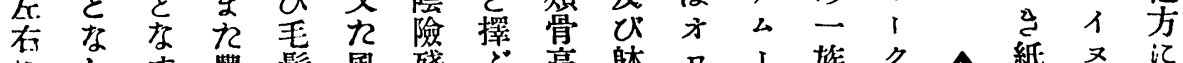

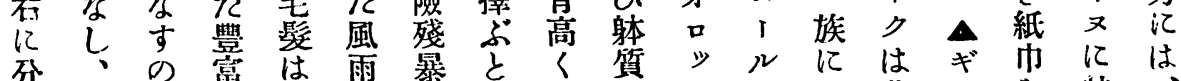

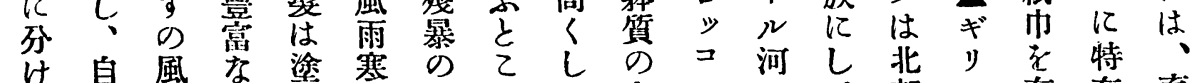
、息等

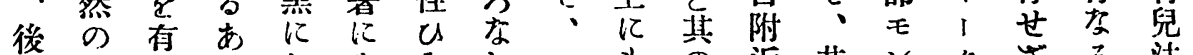

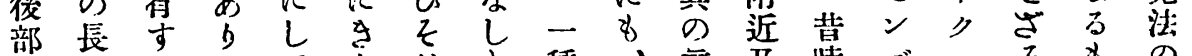

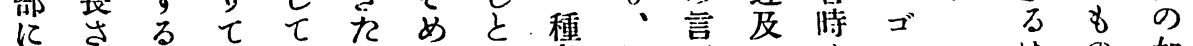

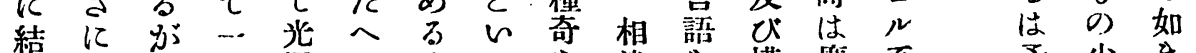

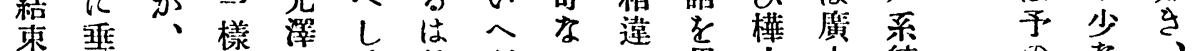
し る

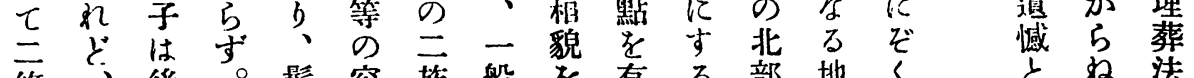
條、後。琴容族般炎有る部地く枟法

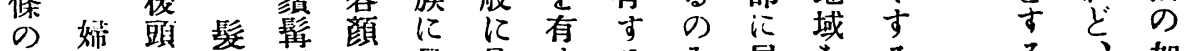

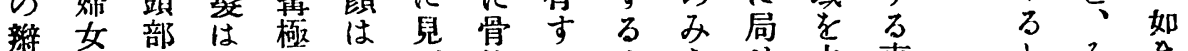

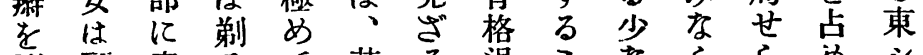

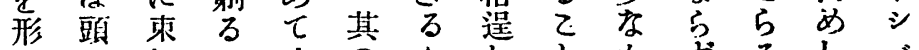

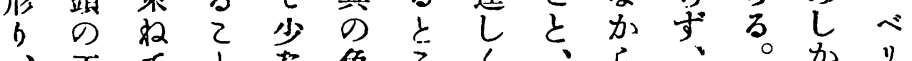

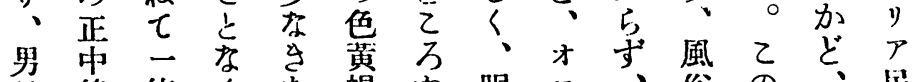

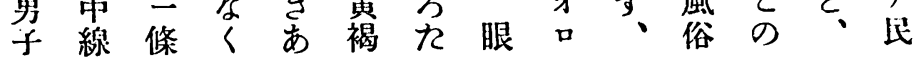

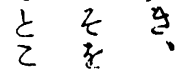

万此何 沿處和 b $ட$ \& 偝 權

何飾引樣にる 總り次る す文し衣遗こ男の

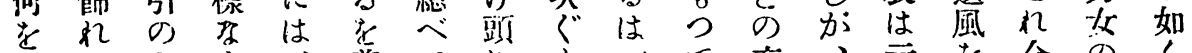

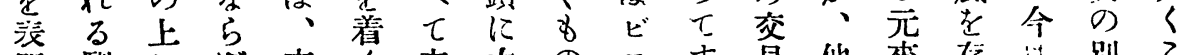

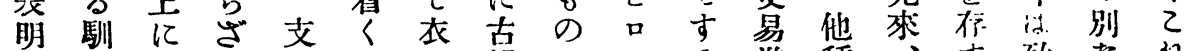

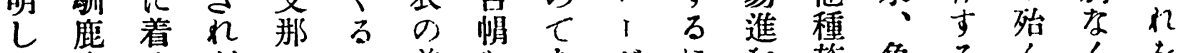

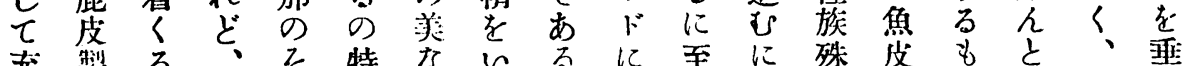

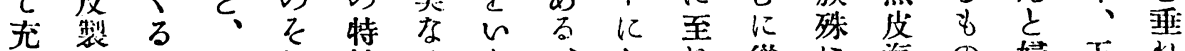

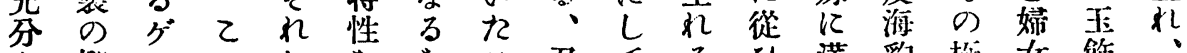

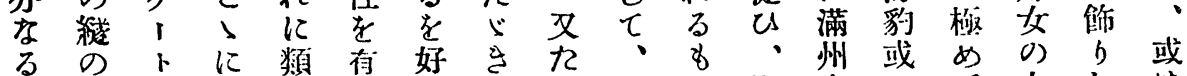

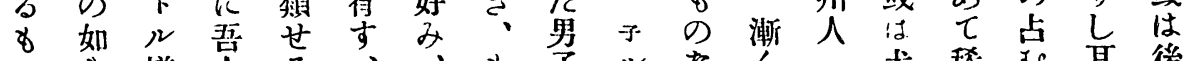

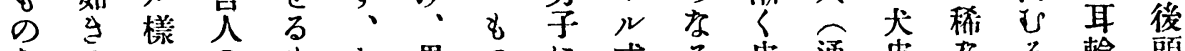

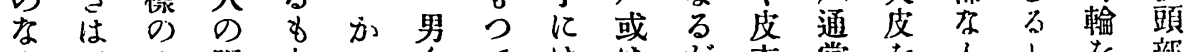

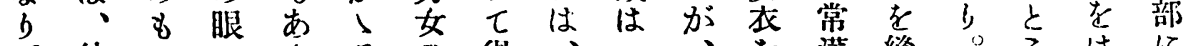

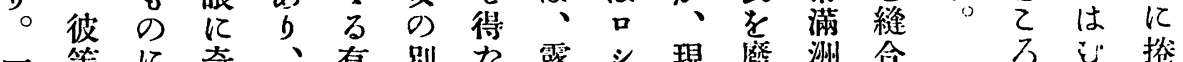
一等に奇 、有别 $九$ 露 $シ$ 現廢洲合方艺挍

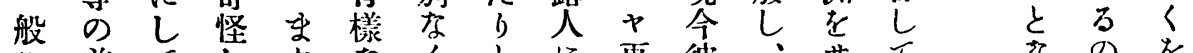

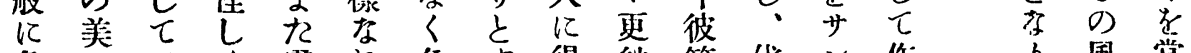

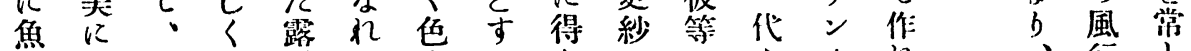
皮對飞映風优夥る九行

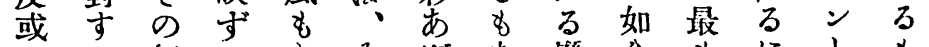
はる紐: る 鍌威のは可の们物は賞綿稱の 豹想端、て 服吕どを之角衣方た

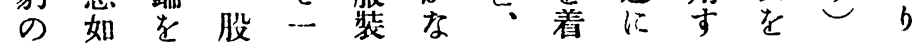

行

男は和

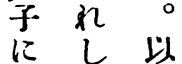
此 肪前 の、は 
號 十七百二第誌雜會學類人京東

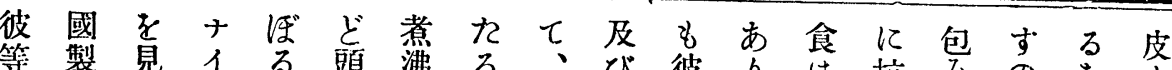

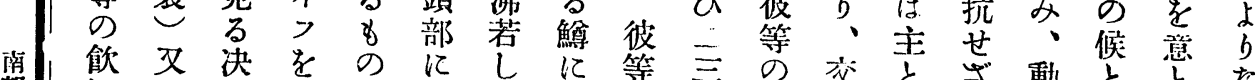

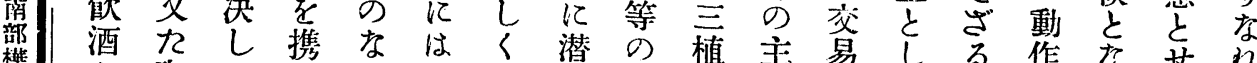

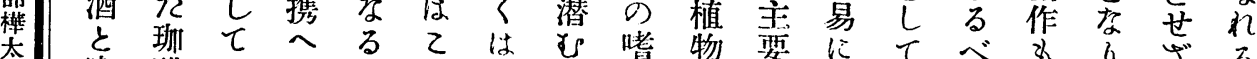

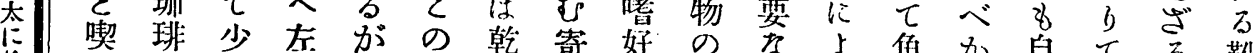

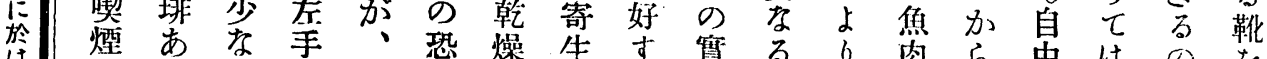

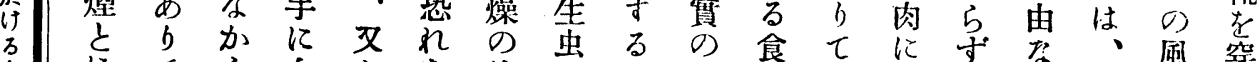
さ 佂

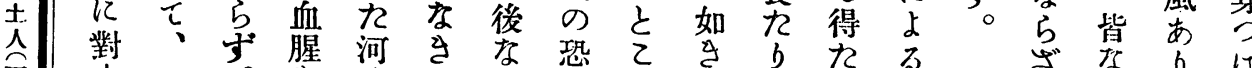

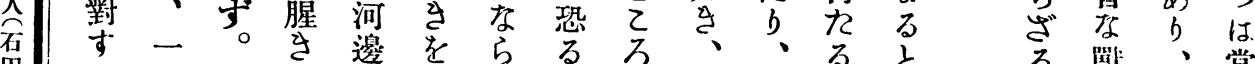

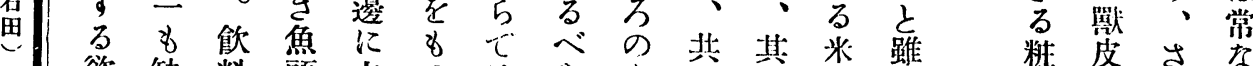

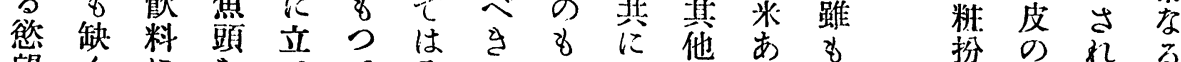

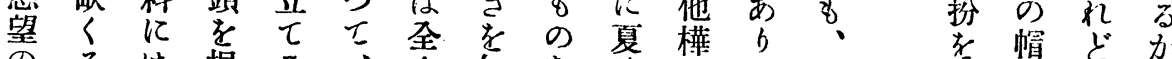

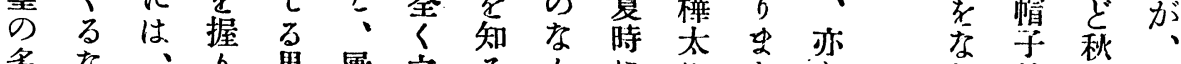

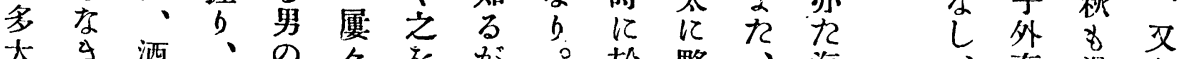

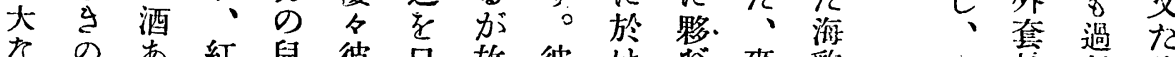
有古紅兒彼口故彼け市麥豹 る 有 b は樣茶唇のののせ、は副さ步り 全るる

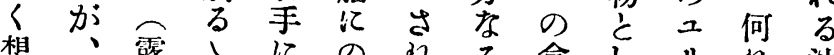

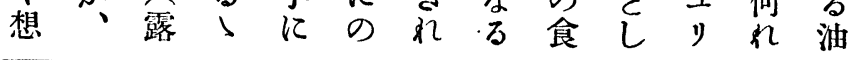

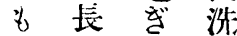

つ靴、足 $\tau$ に寒 酒: 深 四 寒く身 外 寒身老出

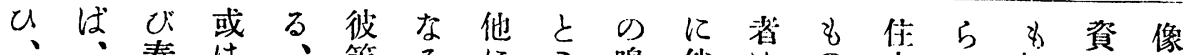

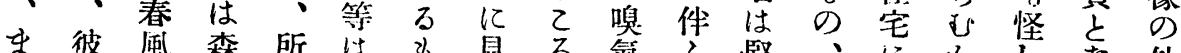

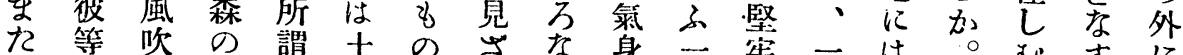

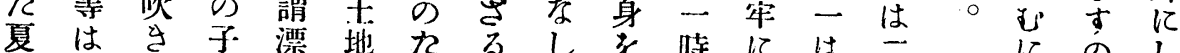
來流來々 泊可方文、壓的し布種

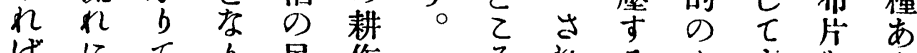

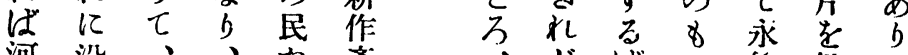
河沿、、文 亿U 河或れ業 網て 海は踣の し 居の 水 、興 七水の期振 鱒下雪子尔

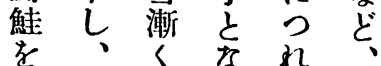
漁專溶る るれ 夢 b 5 け 其 に 海之方分 8 2 豹等 居念 に捕候れ 翼晋 秋獲文ばに有 待從 れ 度 い ぜ

げ線㔔な゙に住縫、

に滴b滴には 北るな、过て露 海河るとる形式 の畔は安にれの 天に、に反る九 地 點 $r$ 極 L 圓 太 に々イめ、錐造 詩散 邓 $\tau$ 後 形 b 趣在の粗者のに をせそには无し 添るれし彼幕元 之文等市方 る の 異、の b 形 多樣な蚞移、李 大はる內任前る
に

足習

万专、 さる 或 るがは 之故 獵 万彼或 、等は 之 J 維 小 今 L ま日它 たあ 獲 人るた 口にる 诚至は 少 b す) ᄂ 直 一は・に 因少 其 
日十二月九年一十四治明

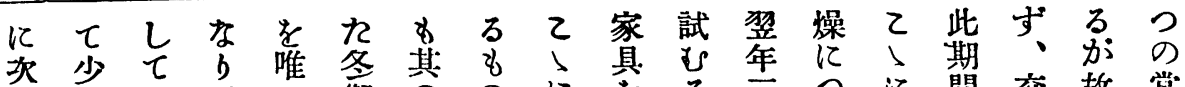

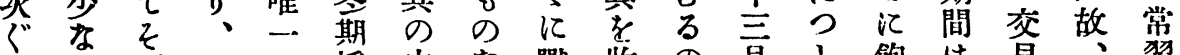

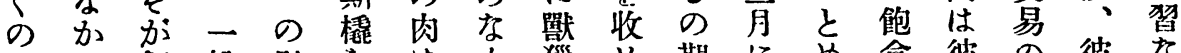

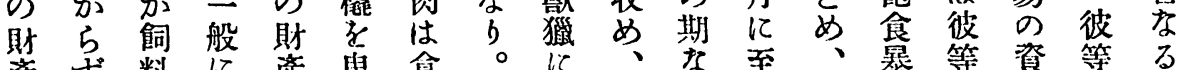

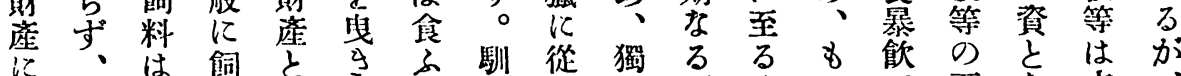

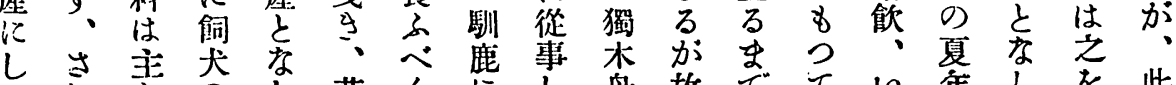

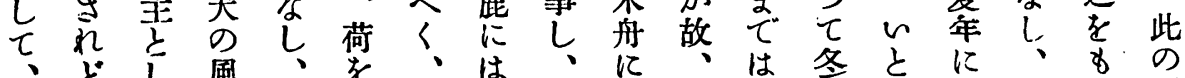

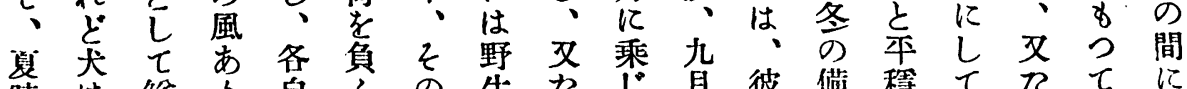

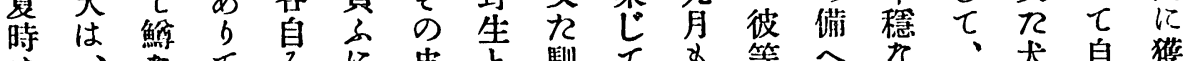

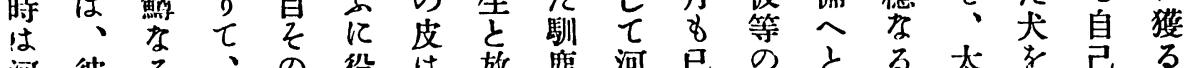

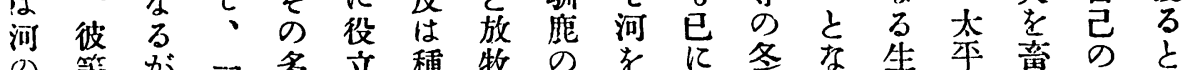

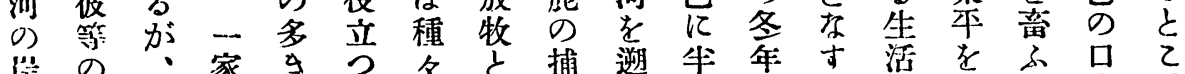

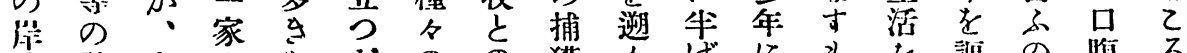

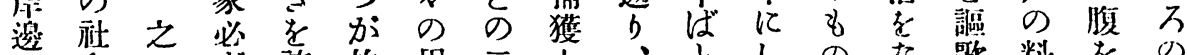

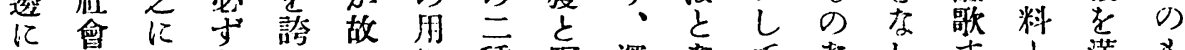

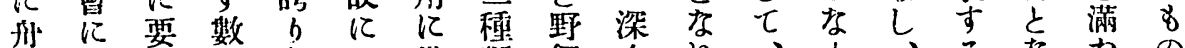
あ杀頭之、供類飼くれ、

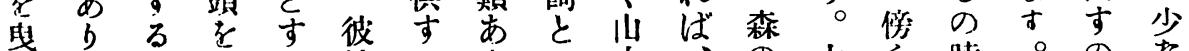

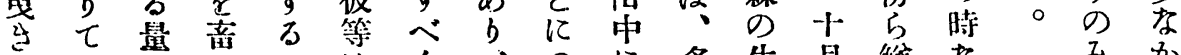

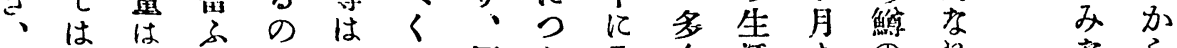

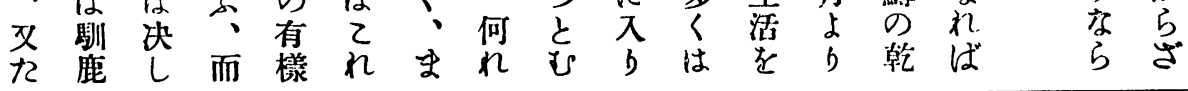

引゙、結して 入

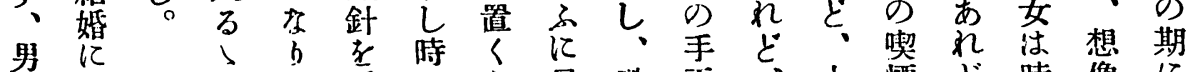

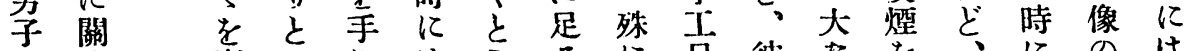

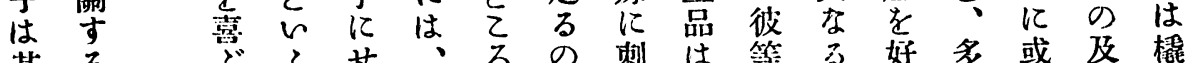
其るぶるせ、万刺は等る好多或及琵

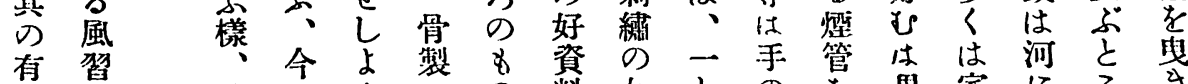
吉は 万.

財 通 虂 常

世 世

主に

と 行

しは

$\tau$ 万

馿

鹿 如

な

औ के

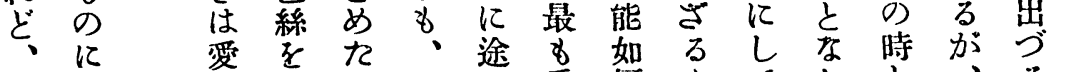
我纪

加 $L$ の 9 料 如

一手管生は河亡曳

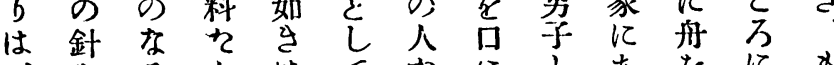

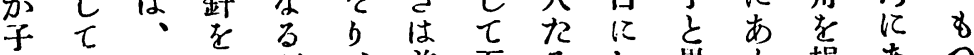

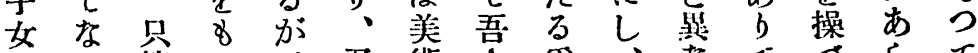

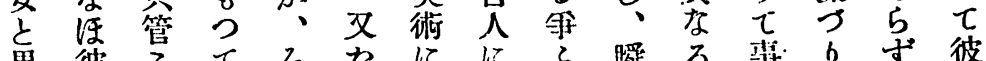

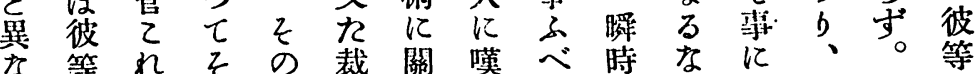
尔等れ

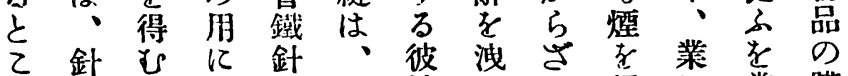
便

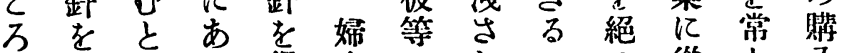

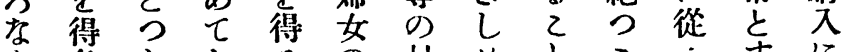

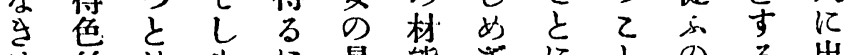

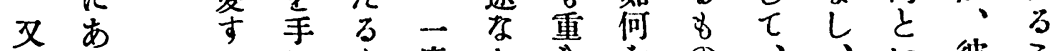

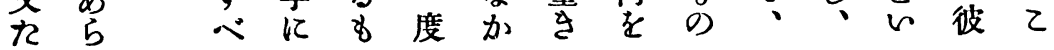
守 多 大 な る 乙 
號十七面二第誌雜會學類人京東

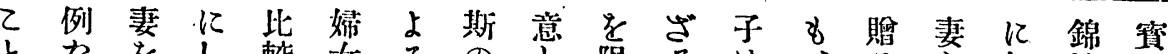

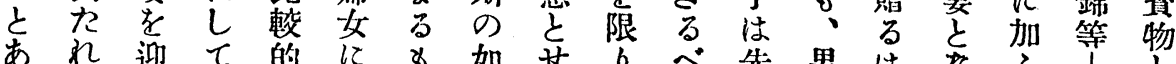
南、㜪 念姅の、嫁多は想

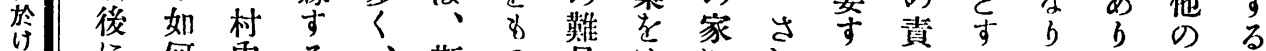

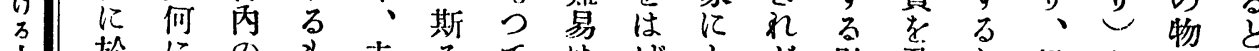

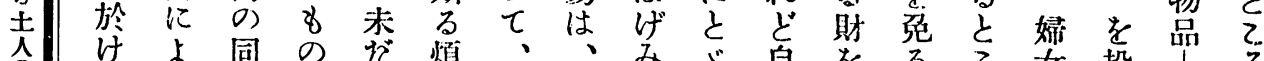

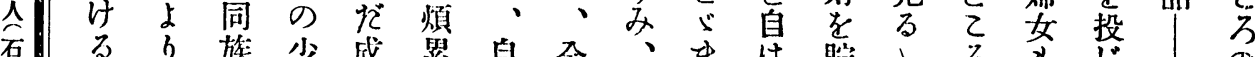

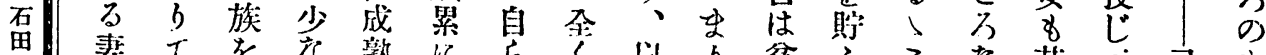

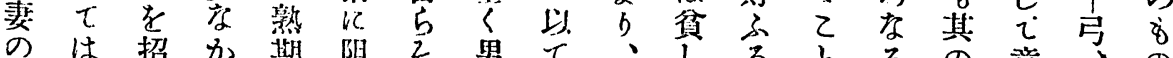

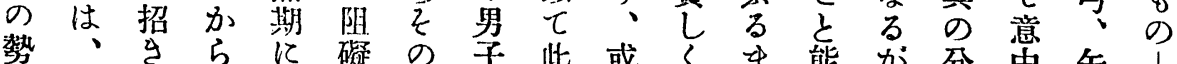

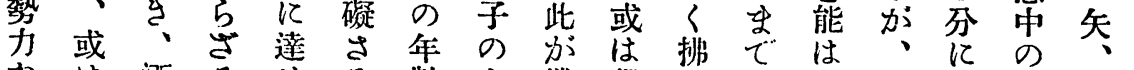

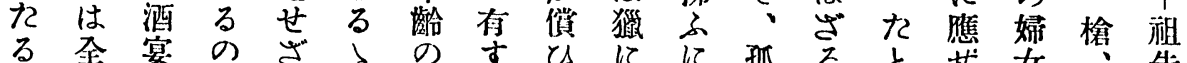

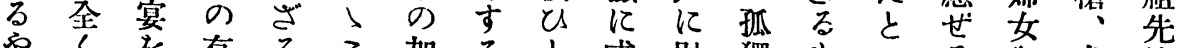

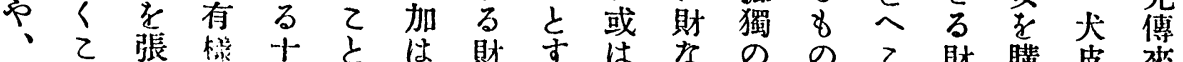

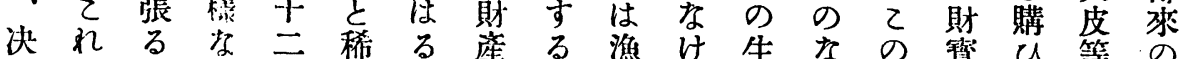
七 鹿

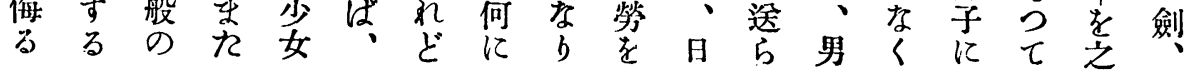

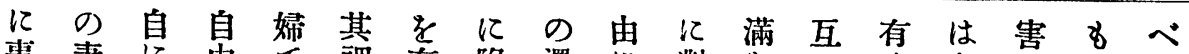

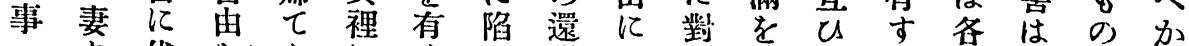

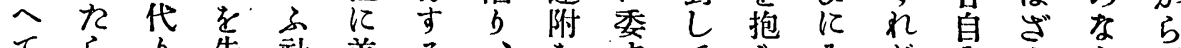

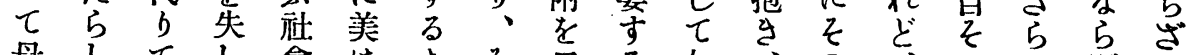

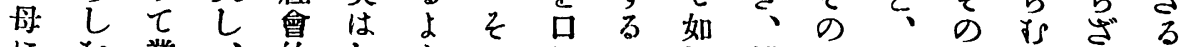

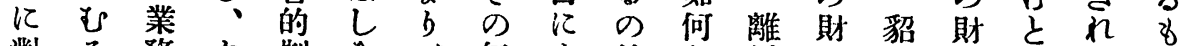

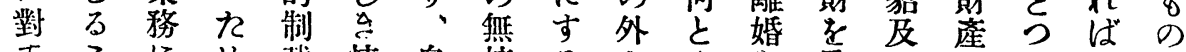

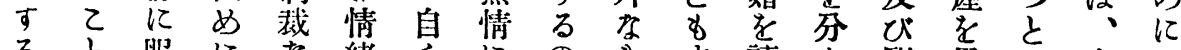

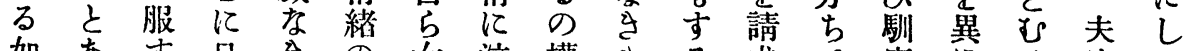

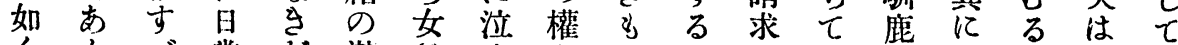

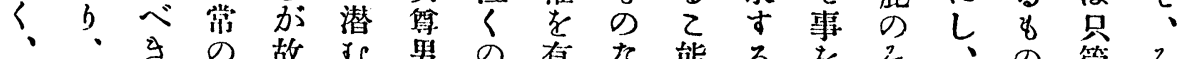

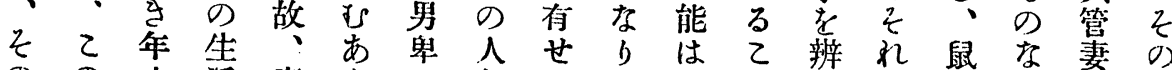

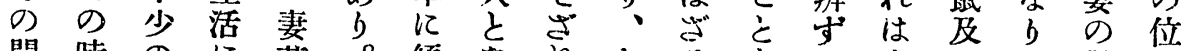

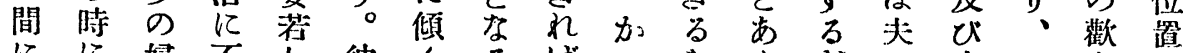

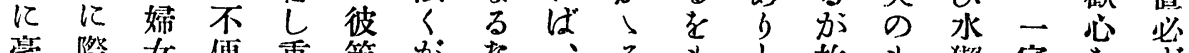

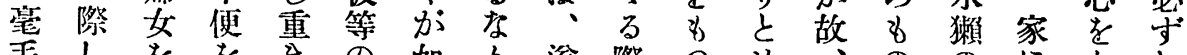

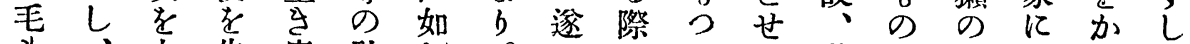

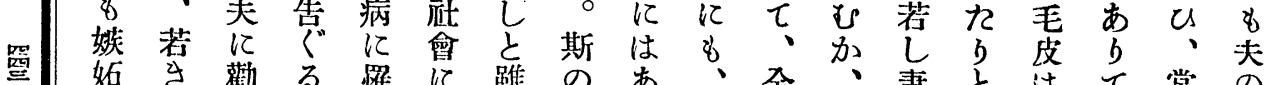

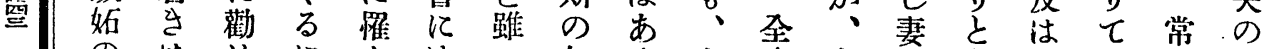

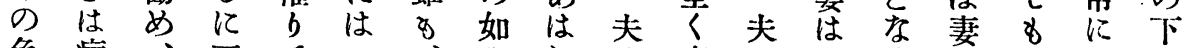

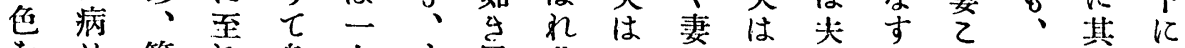

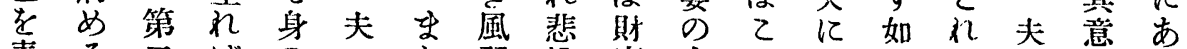

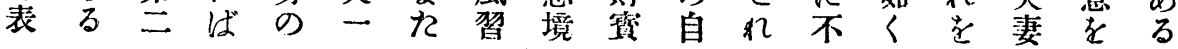


日十二月大等一十四治明

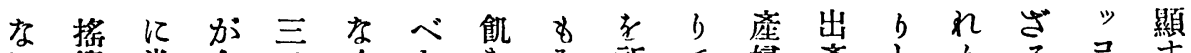

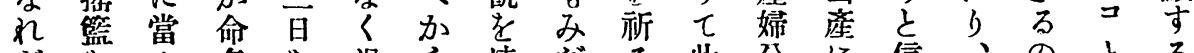

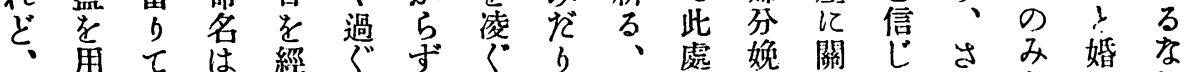

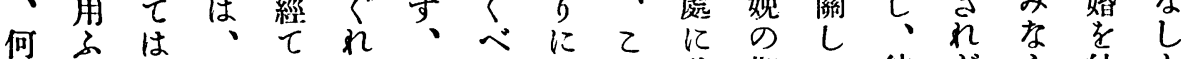

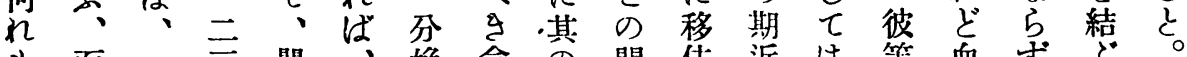

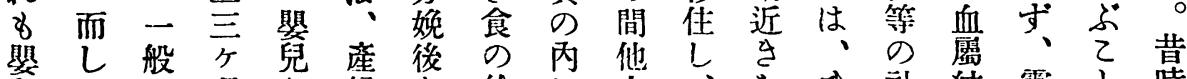

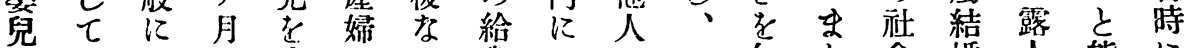
を權の水は痤與人の日知分會婚人能に 安分皮後若㲘此はる同液れ吾にはのはあ 静形或なく兒處、乙搂孤ば公加、妻ざ

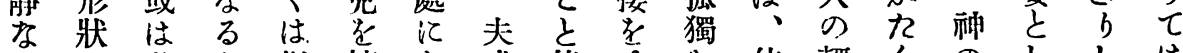

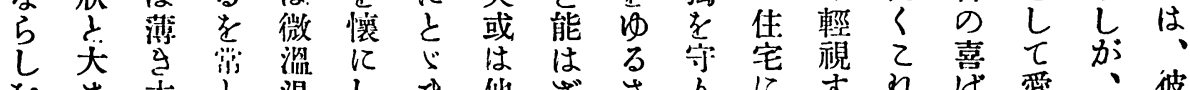
ると板 す

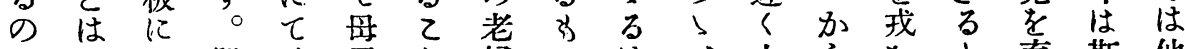

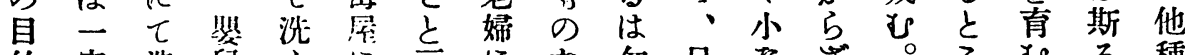

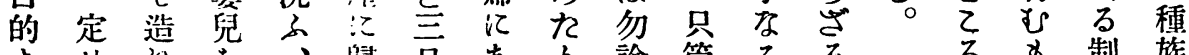

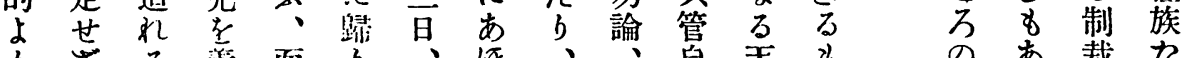

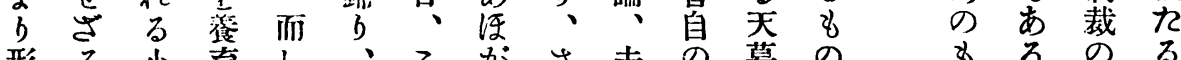
形

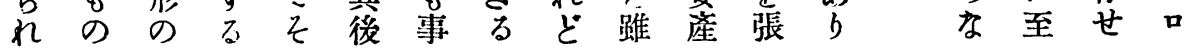

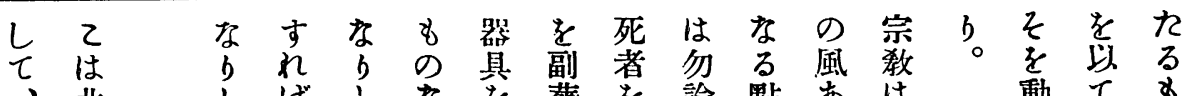

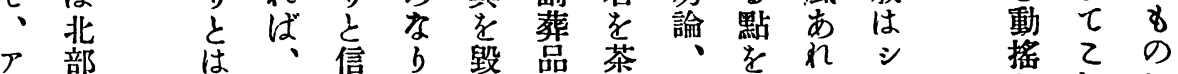

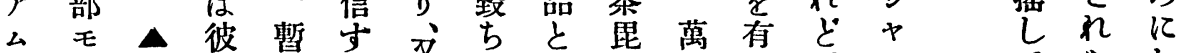
I ע 才 等 $\nu$ ゴ

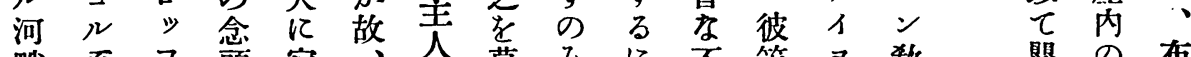
㽗系二頭宿、死墓 小統伅主死点なあ死は、、

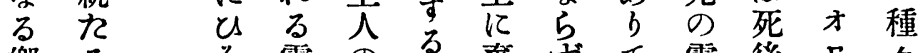
鄉るる靈

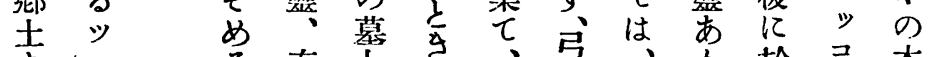

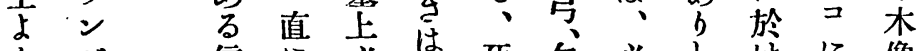
b、ク 信に必は死矢必之けに像

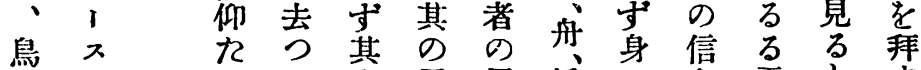

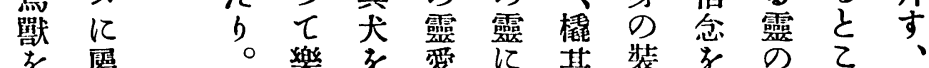

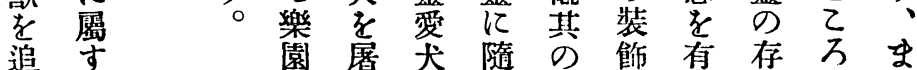
る に秛に件他品卞在の片

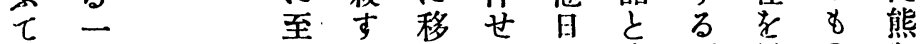
權 種 島 族

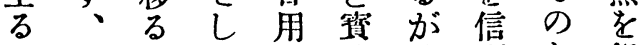
に

名 斯 8 品物 故守と祭

兒 一 片

老隅に

安に包 य 晸 め 眠垂る $b$ 乙 賏 に、兒 入或を 万性

し之の 考丙 䐱江 圈 る 部橫 它行 な抱紐 
號十七百二第誌雜會學類人京東 部で

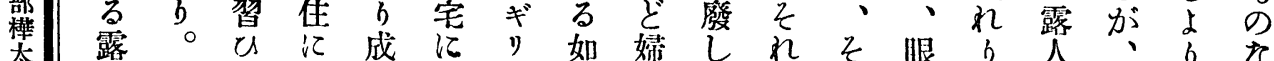

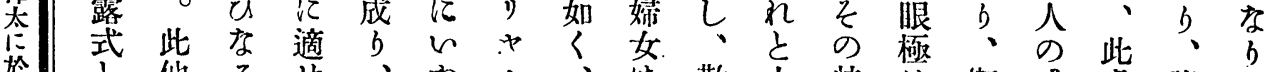
箩 华监る せ

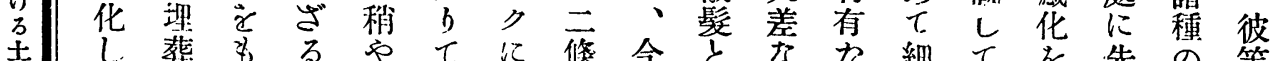
去し、葬

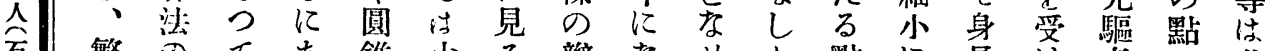

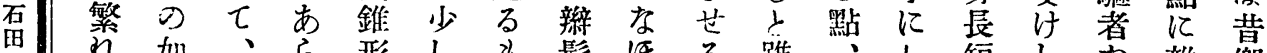

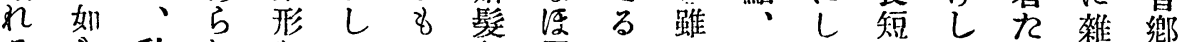

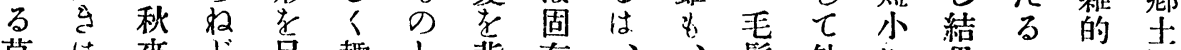

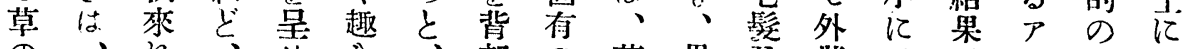

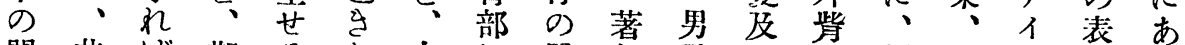

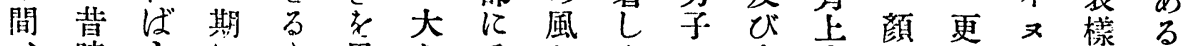

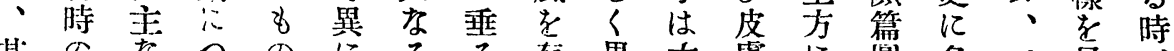

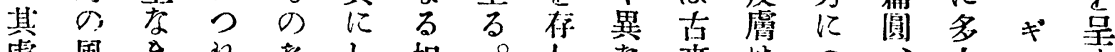

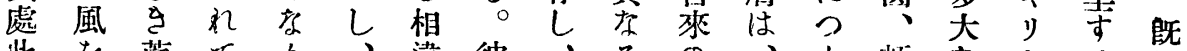

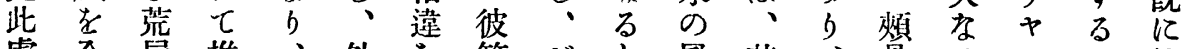
處全屋推、外素等 $キ ゙$ 風其、骨るる、に他 にく之移之堛有の程

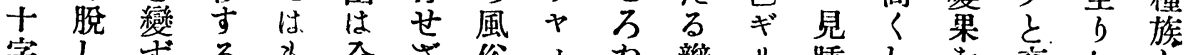

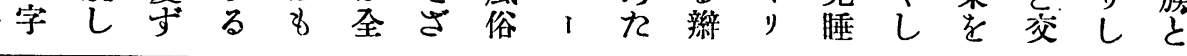

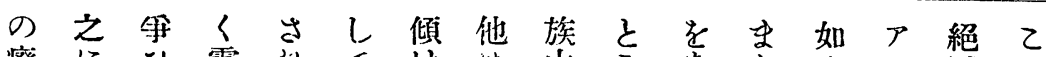

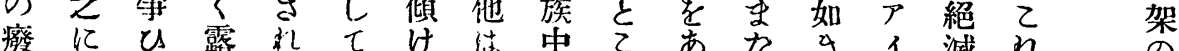

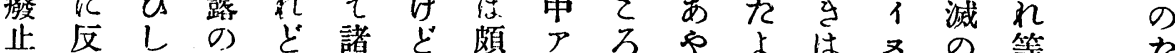

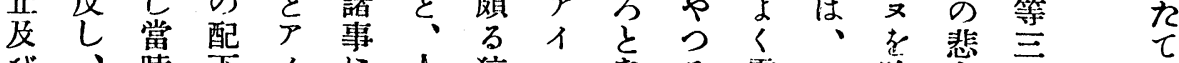

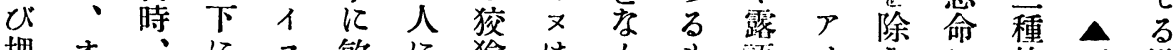
埋オ 烈 法

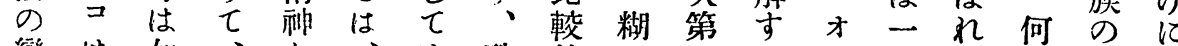

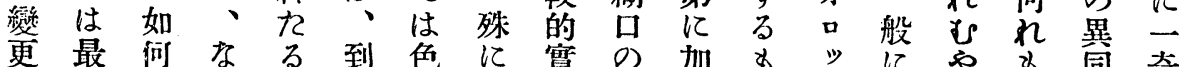

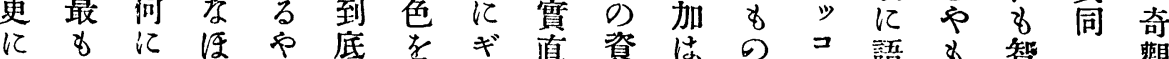

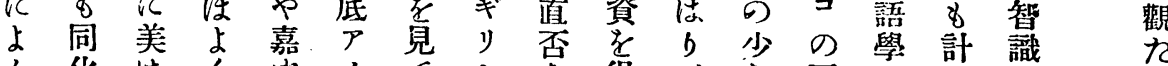

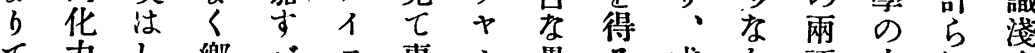
て 力

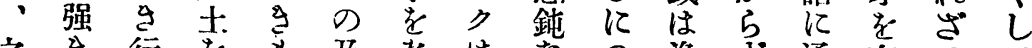

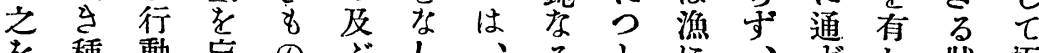

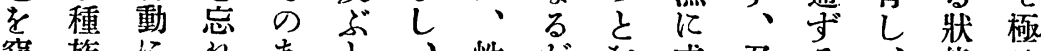

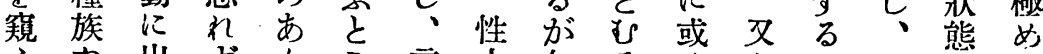

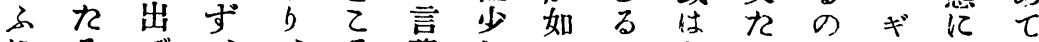
にるで、、万葉しししる邦近みりは微

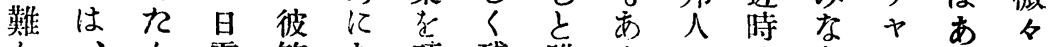
仙、b 露 等 点譬し 珷 は 
日十二月九年一十四治明

ら經於階彼一年めは热に部の万風道る

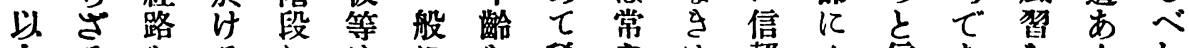

は問学

、題 $b$ 族

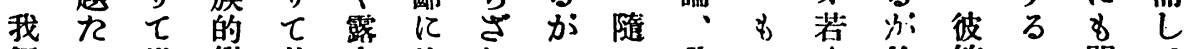

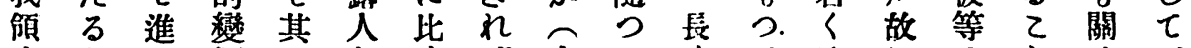

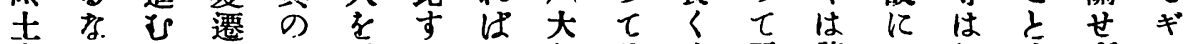

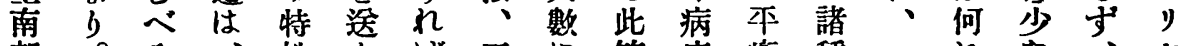

部。马、性 b ば正に等床嬑種一れる、ャ

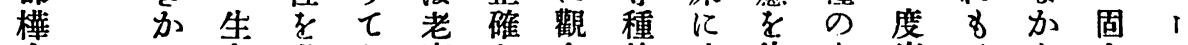

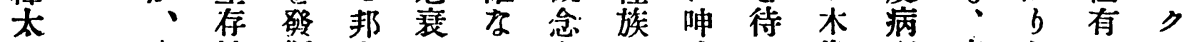

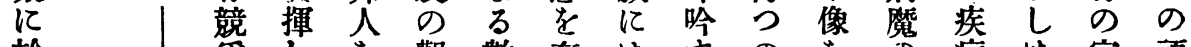

於 爭し老觀數有はすの学病は宗頑

け之填つ迎あをせ、る有着冒を、教迷

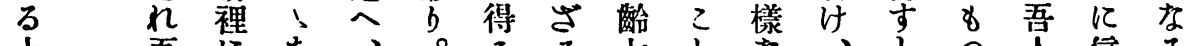

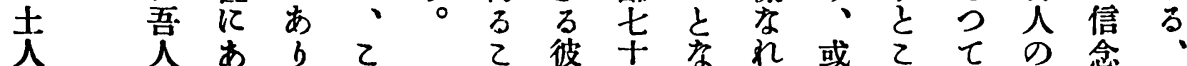

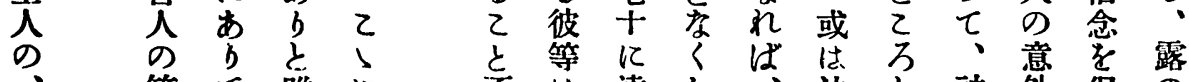

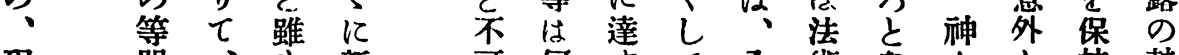

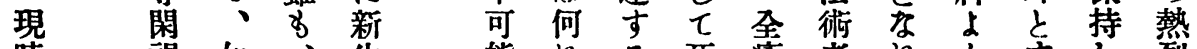

時視如、生能れる死瘾者れ占方し 烈

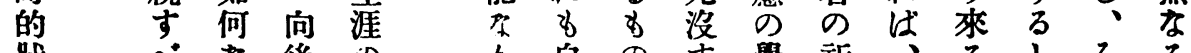

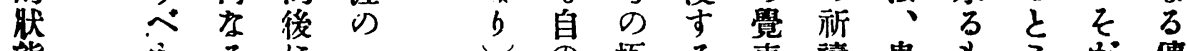

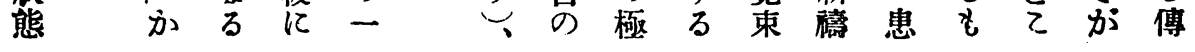

b、俚婦本

神況傳 第

棲方角

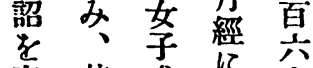

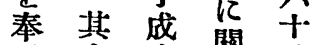

息 女關 號

此毎期 方

蛇に这公

の 流 ぶ 信 I

成市之湿七

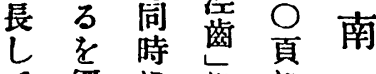

$\tau$ 經 $に$ に

男水、載甫

子主胸越

食守虫米熊

讪 古 或 澤

盡充蛇 万安

寸 智 入地 立

を者て方君

妨蒠のの
足他遺 b 九 加煩に

学漏てるるる。關

惜再あ二や方加せ

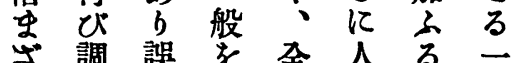

0
湜
齔
就
就

赤住

万查謬推圭種如端

べの 知人學方

し 機るすに的は訅

江は万調此述

接、之九查處世

予

るの能る經省に

2 疑 \& 8 驗 略 過

とはざのな せ

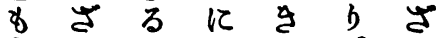

あるはあの。る

占方分身予市

と諭岌、はの

に万、而學に

はて 訅ばし淺し

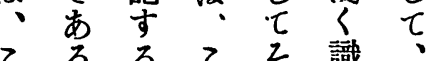

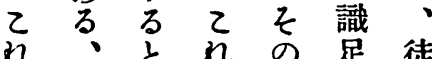

れ社徒

加幸之調占占

補にろよ查すに 
俗風の人土太樺

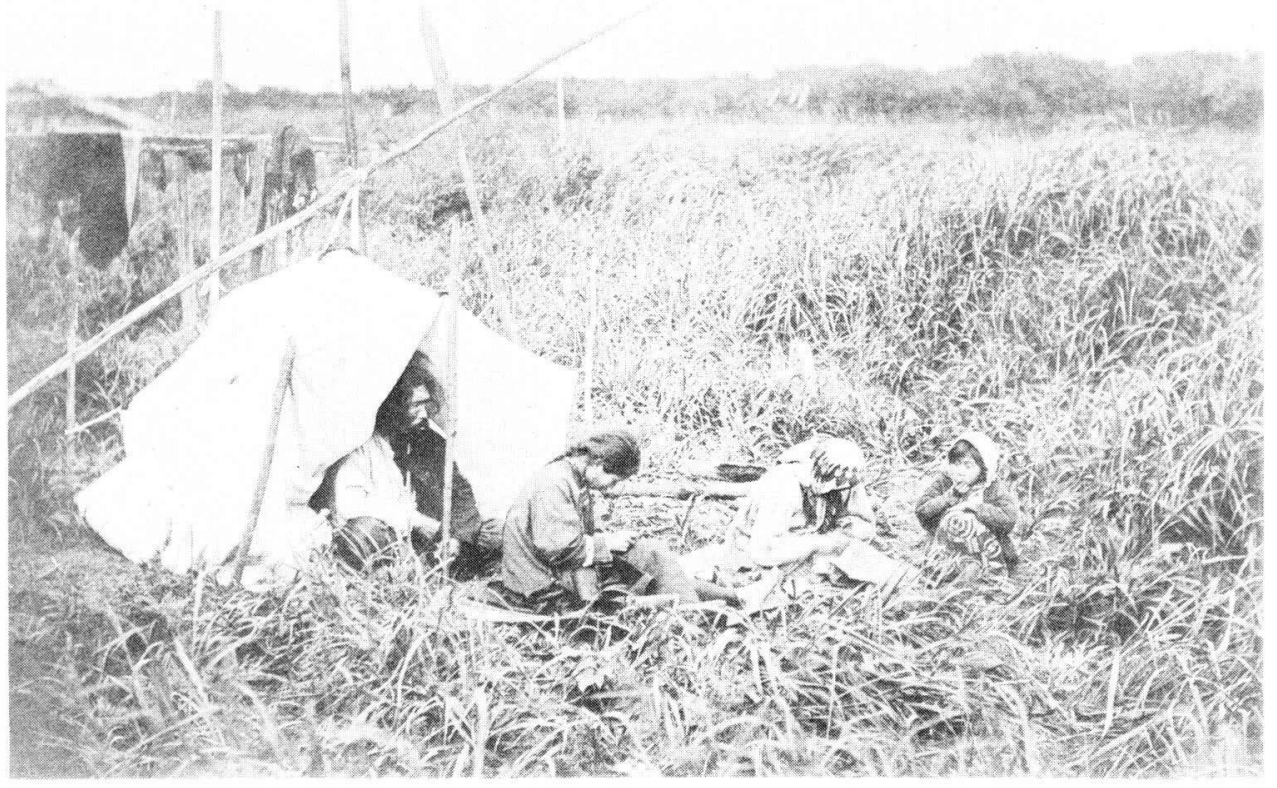

A FAMILY OF GIIIAKS, WITH THIER TENT, SOUTHERN SAGIIAIIEN

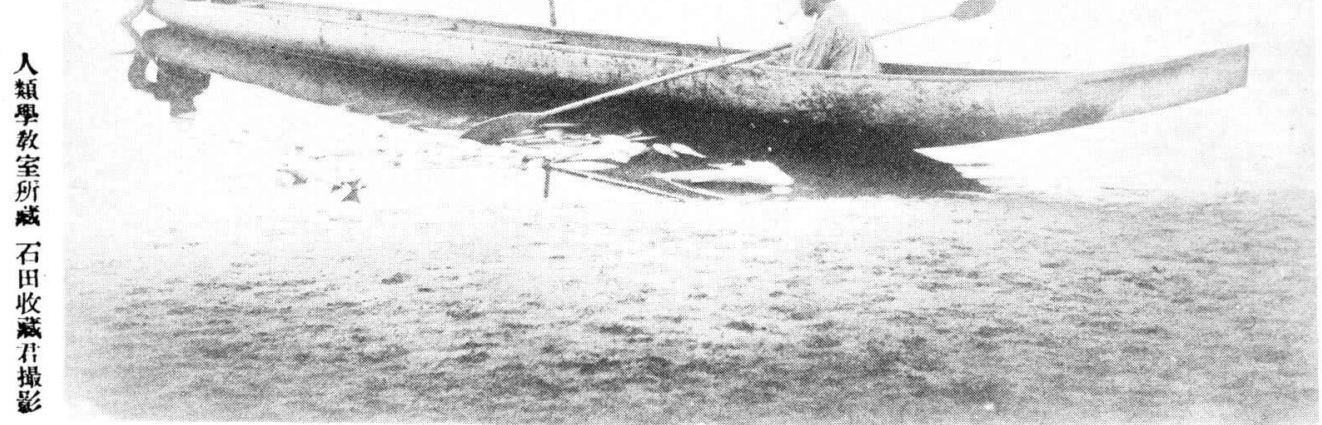

Photo. by Mi. S. Ishida, Anthrop. Imp. Inst., Univ., Tokyo.

TWO OROKES IN A CAN(), FEISHING ON TILE P(ORONAI 